\title{
Chrysophycean Stomatocysts in the Upper Pleistocene and Holocene Sediments from Lake Hovsgol, Northern Mongolia
}

\author{
Alena D. Firsova, Svetlana S. Vorobyova, Yelena V. Likhoshway \\ Limnological Institute, Siberian Branch, Russian Academy of Sciences, Irkutsk, Russia \\ Email: firsova@lin.irk.ru
}

Received September 7, 2011; revised October 8, 2011; accepted October 17, 2011

\begin{abstract}
Siliceous stomatocysts of chrysophyte algae, along with diatom frustules, are well preserved in bottom sediments of various water bodies. Analysis of microfossils from a core sample of the Upper Pleistocene and Holocene sediments from the southern part of Lake Hovsgol revealed 36 different morphotypes of chrysophycean stomatocysts. Some of them were attributed to species of the genera Mallomonas Perty, Chrysosphaerella Lauterborn., Paraphysomonas (Stokes) De Saedeleer, and Dinobryon Ehr.; 20 morphotypes were described as novel. The abundance and diversity of stomatocyst morphotypes in the core sample varied depending on the age of sediments. The results obtained in the study broaden views on the biological diversity of microalgae and confirm that chrysophycean stomatocysts can serve as good environmental indicators in paleolimnological and paleoclimatic reconstructions.
\end{abstract}

Keywords: Chrysophycean Stomatocysts; Diatoms; Lake Hovsgol; Mongolia; Upper Pleistocene; Holocene

\section{Introduction}

Bottom sediments of Lake Hovsgol, which are approximately $550 \mathrm{~m}$ deep [1], reflect the history of climate change as well as the history of the lake itself. Drill core samples of sediments formed over the past million years have been obtained and analyzed to make paleoclimatic and paleolimnological reconstructions [2-7]. Palynological and diatom analyses of core samples from the central and northern parts of the lake have revealed specific features of the climate of Mongolia during the Holocene and have shown that fluctuations in the concentration of microfossils depend not only on climatic changes but also on variation in the level and, probably, salinity of water in the lake $[2,4,8]$.

A palynological analysis of the Upper Pleistocene and Holocene sediments from the deep-water part of Lake Hovsgol has resulted in identification of six palynozones indicative of the following climatic sequence: a sharply continental climate with a deficiency of atmospheric moisture supply about $14 \mathrm{ka} \mathrm{BP}$; a milder climate with higher winter and summer temperatures and increasing atmospheric moisture between 9.5 and $6.5 \mathrm{ka} \mathrm{BP}$; a cool and moist climate during the Holocene optimum, which ended about $6 \mathrm{ka} \mathrm{BP}$; the prevalence of dry and warm climate between 5.5 and $3.5 \mathrm{ka} \mathrm{BP}$; and the development of climatic conditions close to those prevailing today beginning from $3.5-3.0 \mathrm{ka} \mathrm{BP}$ [5].

According to the reconstruction made by Fedotov et al. (2004), a cold and dry climate in the Late Pleistocene caused a significant drop of water level and reduction of surface area in the lake, with its southern part drying up. As follows from the results of palynological and diatom analyses [8], such events also repeatedly took place during the Holocene (in particular, 6500 - 5400, 4900 - 4000, and $2600-1800$ years BP).

The water level in Lake Hovsgol increased at the end of the Pleistocene, about $15 \mathrm{ka}$ BP [6]. This follows from a general increase in the total concentration of diatoms in bottom sediments and the appearance of planktonic diatom species in sediment samples from the central and northern parts of the lake $[1,2]$. In the Holocene, the lake was inhabited by a limited number of planktonic diatom species [1,2,9]: Cyclotella ocellata Pant. dominated throughout this time, with Cyclostephanos dubius (Fricke) Round being a codominant species. The period from the beginning of the Holocene to $5.5 \mathrm{ka} \mathrm{BP}$ was marked by active development of Cyclotella bodanica Grunow, the pelagic species widely occurring in Pleistocene and Holocene sediments as well as in recent water bodies [10]. The endemic species Stephanodiscus mongolicus M. B. Edlund, N. Soninkhishig \& R. M. Williams appeared in the lake phytoplankton about $8.5 \mathrm{ka}$ BP [2,4]. These facts can be used for stratigraphic correlation of Holo- 
cene sediment samples from Lake Hovsgol.

Along with diatoms, siliceous stomatocysts of chrysophyte algae (also referred to as statospores, statocysts, or simply cysts) have been found in bottom sediments from Lake Hovsgol, but the available published data concern only changes in their total abundance [4-7].

The purpose of this research was to study the morphology of chrysophycean stomatocysts by means of scanning electron microscopy (SEM) and to analyze the pattern of their distribution in a core sample of sediments from the southern part of Lake Hovsgol, which was stratigraphically correlated with previously studied sediment cores on the basis of diatom analysis. We described novel morphotypes of stomatocysts, characterized the diversity of these morphotypes in the Upper Pleistocene to Holocene sediments, and showed that their distribution changes with depth down the sediment profile, which is the reason for regarding them as an additional indicator of change in environmental conditions that has been preserved in the paleorecords of Lake Hovsgol.

\section{Material and Methods}

Studies were performed with the sediment core HUB 01-01, $107 \mathrm{~cm}$ long, taken in the southern part of Lake Hovsgol (50 $\left.41^{\circ} 57^{\prime \prime N}, 100^{\circ} 21^{\prime} 11^{\prime \prime E}\right)$ from a depth of 160 $\mathrm{m}$ (Figure 1).

Diatom analysis and total enumeration of stomatocysts were performed as described [11], with sediments from the core being sampled at $1-\mathrm{cm}$ intervals and analyzed under an Amplival light microscope (Carl Zeiss, Germany). SEM analysis (Philips SEM 525 M microscope, the Netherlands) was used for more accurate species identification of diatoms and morphological description of stomatocysts.

Since the taxonomic position of most stomatocysts remained unknown, they were described as morphotypes, according to recommendations of the International Statospore Working Group (ISWG), which are generally accepted today [12-15]. Each morphotype was assigned an individual number with index $\mathrm{H}$ (Hovsgol).

Concentrations of diatoms (frustule valves) and stomatocysts were expressed as their numbers per gram air-dry sediments. These concentrations were used to calculate the ratio of diatoms, both planktonic and benthic (D), to cysts (C), or the D/C index [16]. The species (morphotypes) accounting for more than $10 \%$ of the total abundance of diatoms (stomatocysts) was regarded as dominant.

\section{Results}

\subsection{Diatom Stratigraphy}

The HUB 01-01 sediment core was correlated with the

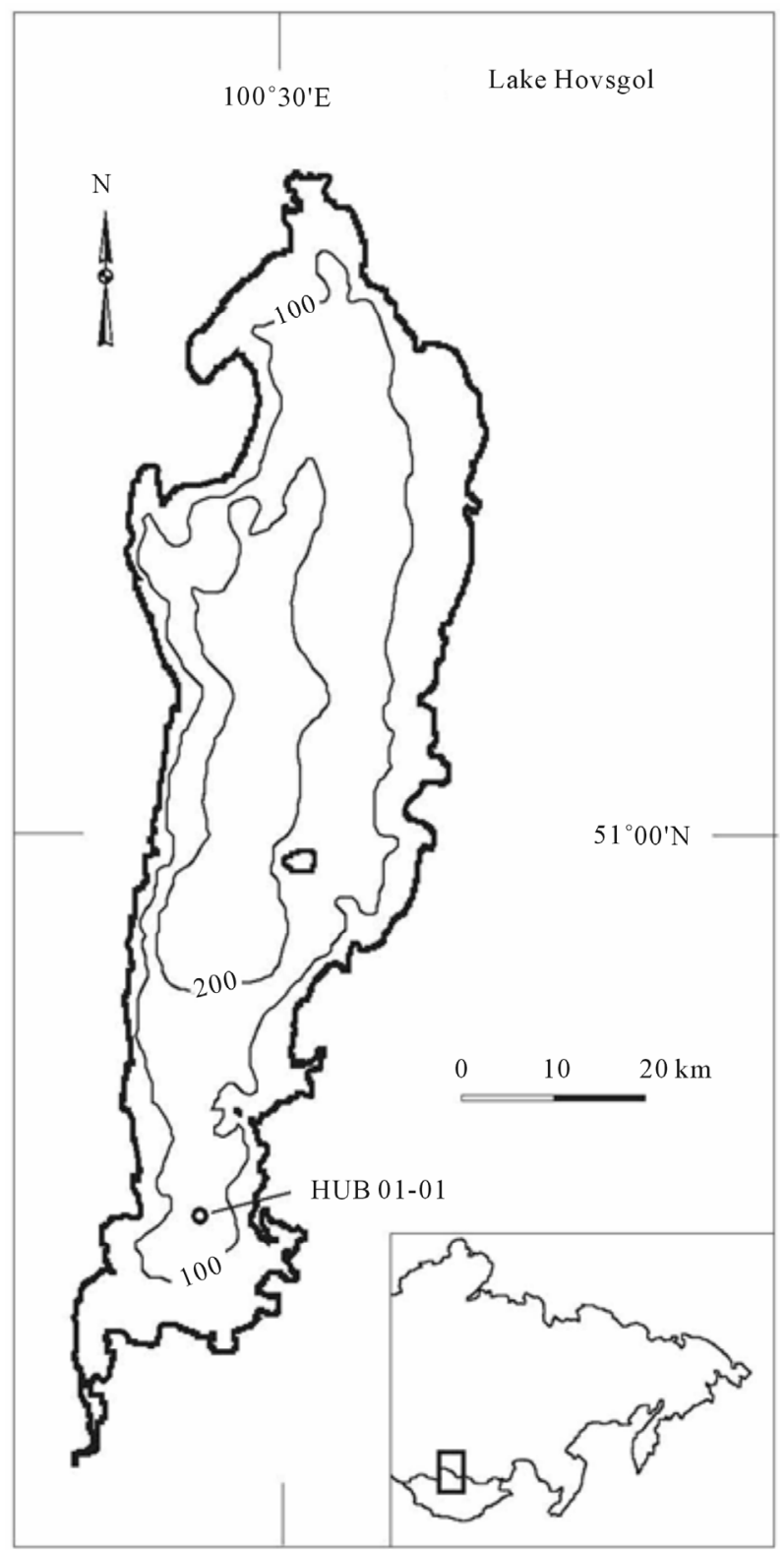

Figure 1. Bathymetric map of Lake Hovsgol and location of the HUB 01-01 core sampling site.

previously dated core X105-2 from the central depression of the lake [2] with respect to the distribution pattern of dominant diatom species (Figure 2). The HUB 01-01 core was found to cover the period from the end of the Pleistocene through the Holocene, and several intervals were distinguished in it.

1) $107-83 \mathrm{~cm}$ : Dominance of benthic species after a diatom-barren interval. The appearance of benthic diatoms at a core depth of $96 \mathrm{~cm}$ and their dominance over planktonic species (up to $74 \%$ at $93-90 \mathrm{~cm}$ ) provide evidence for the existence of a shallow water body in place of the present-day southern depression.

2) $82-77 \mathrm{~cm}$ : A short-term, sharp increase in the 


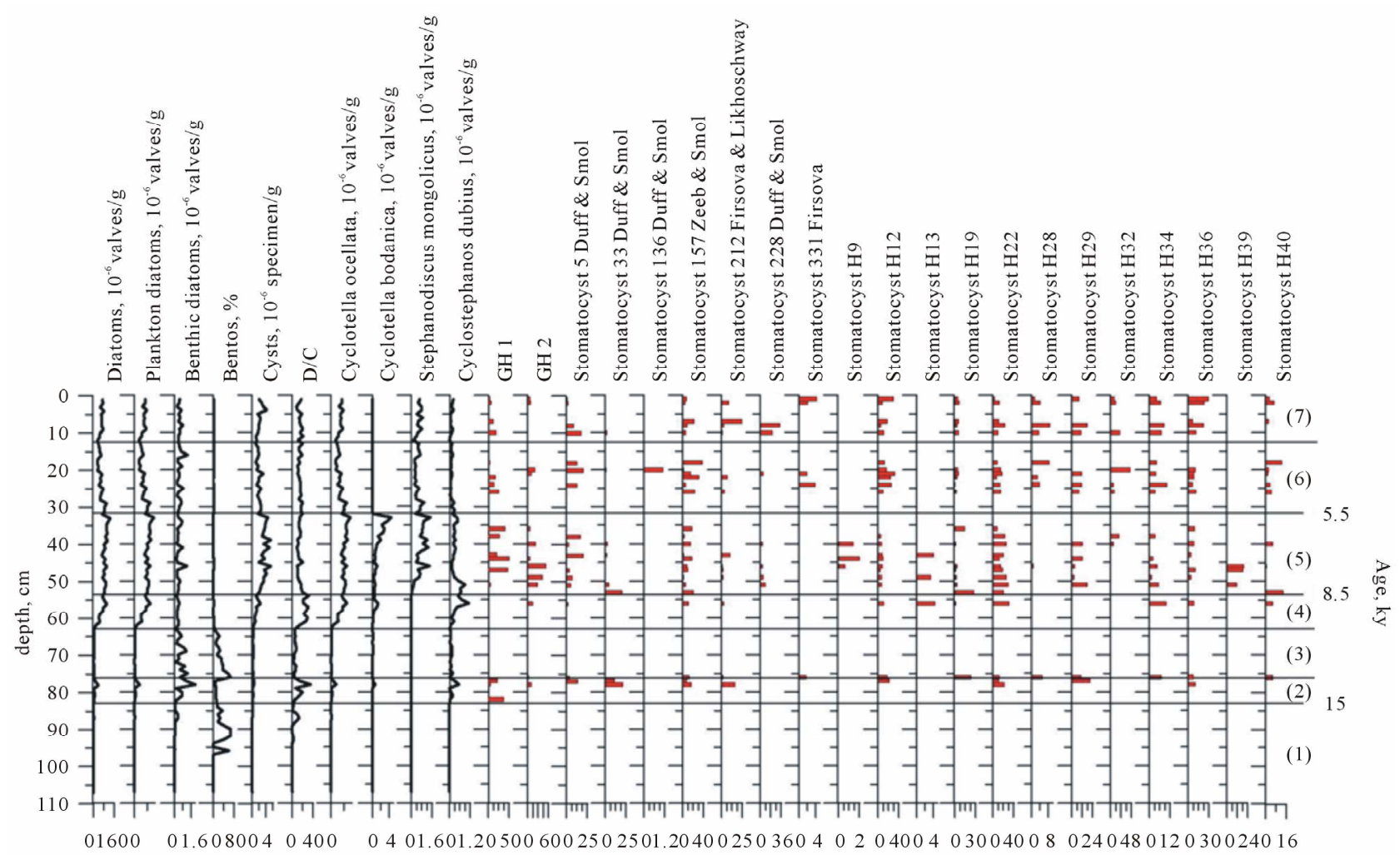

Figure 2. Distribution patterns of diatom frustules, chrysophycean stomatocysts, and their individual morphotypes (proportion of the total number of stomatocysts, \%) in the Upper Pleistocene to Holocene sediments from Lake Hovsgol.

concentration of planktonic diatoms. The dominance of planktonic diatoms, with a local peak at $78 \mathrm{~cm}$ (Cyclotella ocellata, up to $32 \times 10^{6}$ valves/g; C. bodanica, up to $0.6 \times 10^{6}$ valves $/ \mathrm{g}$; and Cyclostephanos dubius, up to $0.54 \times 10^{6}$ valves $/ \mathrm{g}$ ), is indicative of significant water deepening.

3) 76 - $63 \mathrm{~cm}$ : An interruption in the accumulation of planktonic diatoms, with dominance of benthic species. A high relative content of benthic diatoms (up to $68 \%$ at $76 \mathrm{~cm}$ ) may reflect an episode of lake shallowing during the dry and cold climate of the Late Dryassic and Early Holocene.

4) 62 - $54 \mathrm{~cm}$ : Active development and eventual dominance of planktonic diatoms, with the relative content of benthic species decreasing. Global climate warming in the Early Holocene is reflected in the increased abundance of microfossils in bottom sediments, with the proportion of benthic diatoms dropping to no more than $1 \%-2 \%$ and remaining at this level. Cyclotella ocellata gains dominance, accounting for up to $97 \%-99 \%$ of the total diatom abundance $\left(100 \times 10^{6}\right.$ valves/g); other distinctive species, as in interval 2 , are C. bodanica and C. dubius (about $1 \%$ each; up to $1.3 \times$ $10^{6}$ and $1.1 \times 10^{6}$ valves/g, respectively).

5) 53 - $32 \mathrm{~cm}$ : The interval marked by the appearance of $S$. mongolicus and disappearance of $C$. bo- danica. The total concentration of diatoms is high, varying within the range of $(64.4-127.8) \times 10^{6}$ valves $/ g$. The corresponding period was most favorable for the development of $S$. mongolicus and $C$. bodanica. The former species first appeared in the core at a depth of $53 \mathrm{~cm}(20$ $\times 10^{3}$ valves $\left./ \mathrm{g}\right)$. This diatom successfully colonized the pelagic zone of the lake, which follows from the tenfold increase in its concentration at a core depth of $50 \mathrm{~cm}$ and the next sevenfold increase (up to $1.4 \times 10^{6}$ valves $/ \mathrm{g}$ ) at $46 \mathrm{~cm}$. After reaching a peak of $1.46 \times 10^{6}$ valves $/ \mathrm{g}$ at $33 \mathrm{~cm}$ (at the end of the interval), the concentration of $S$. mongolicus dropped sharply and remained below $1 \times$ $10^{6}$ valves/g in the upper core sections. Likewise, the concentration of $C$. bodanica reached a peak of $4.5 \times 10^{6}$ valves $/ \mathrm{g}$ at $33 \mathrm{~cm}$, which was followed by its sharp drop to $30 \times 10^{3}$ valves $/ \mathrm{g}$ and then, at $32 \mathrm{~cm}$, to only a few valves per gram.

6) $31-12 \mathrm{~cm}$ : A trend toward a decrease in the concentration of planktonic diatoms, mainly on account of C. ocellata. After a short-term cooling (5.5 ka BP) followed by a warm and dry climate, the total contents of diatoms in bottom sediments decreased, varying within the range of $(28.6-99.2) \times 10^{6}$ valves $/ g$.

7) 11 - $0 \mathrm{~cm}$ : Stabilization of the concentrations of planktonic and benthic diatoms. In the Late Holocene, the concentration of planktonic diatoms increased slightly 
and stabilized at $45.8-79.7 \times 10^{6}$ valves $/ g$, with the composition of dominant species remaining unchanged to the present day. The concentration of benthic diatoms remained low, $(0.2-0.8) \times 10^{6}$ valves $/ g$.

In addition to diatom frustules, the sediment core contained siliceous stomatocysts of chrysophyte algae. As follows from Figure 2, the total concentration of cysts (C) changed with core depth. Their distribution pattern generally corresponded to those of total diatoms (D) and planktonic diatoms, but the $\mathrm{D} / \mathrm{C}$ values sharply varied along the core. These variations as well as the distribution of individual stomatocyst morphotypes can provide additional information on the diversity of fossil microalgae and changes in the lake ecosystem.

\subsection{Diversity of Stomatocyst Morphotypes}

A total of 36 morphotypes of chrysophycean stomatocysts were identified in the sediment core. Among them, 20 morphotypes proved to be new for science (Figure 3). Their descriptions are given below.

Stomatocyst H8 Firsova (Figure 3(1))

Taxonomic position: Unknown.

Image no.: 8138-1.

Location: The Holocene, Lake Hovsgol.

SEM description: The stomatocyst is spherical, 3.8 $\mu \mathrm{m}$ in diameter, with a cylindrical collar (diameter $1 \mu \mathrm{m}$, height $0.3 \mu \mathrm{m}$ ) pointed at the apex, a flat ridge in the anterior part (base diameter $1.4 \mu \mathrm{m}$, height $0.4 \mu \mathrm{m}$ ), and two to four small indentations at the equator. The pore, $0.5 \mu \mathrm{m}$ in diameter, is surrounded by a small annulus (width $0.2 \mu \mathrm{m}$ ).

Stomatocyst H9 Firsova (Figure 3(2))

Taxonomic position: Unknown.

Image no.: 8137-9.

Location: The Holocene, Lake Hovsgol.

SEM description: The stomatocyst is spherical $11 \mu \mathrm{m}$ in diameter. The collar is absent. The cyst surface is ornamented with small verrucae $0.2-0.4 \mu \mathrm{m}$ in diameter (a total of about 30) in the anterior part and with spinelike processes $0.5-1 \mu \mathrm{m}$ in length, swollen at the base (about 40 ), in the posterior part. The pore is cone-shaped, $1 \mu \mathrm{m}$ in diameter, without the annulus.

Stomatocyst H10 Firsova (Figure 3(3))

Taxonomic position: Unknown.

Image no.: 8136-11.

Location: The Holocene, Lake Hovsgol.

SEM description: The stomatocyst is spherical, 12.6 $\mu \mathrm{m}$ in diameter, without the collar. The cyst surface in the anterior part is irregularly ornamented with small indentations (diameter $0.5-0.8 \mu \mathrm{m}$ ) and verrucous processes (diameter $0.2-0.3 \mu \mathrm{m}$; a total of about 30 ); in the posterior part, verrucous and spinelike processes swollen at the base (the former $0.6 \mu \mathrm{m}$ in diameter, the latter 0.5 -

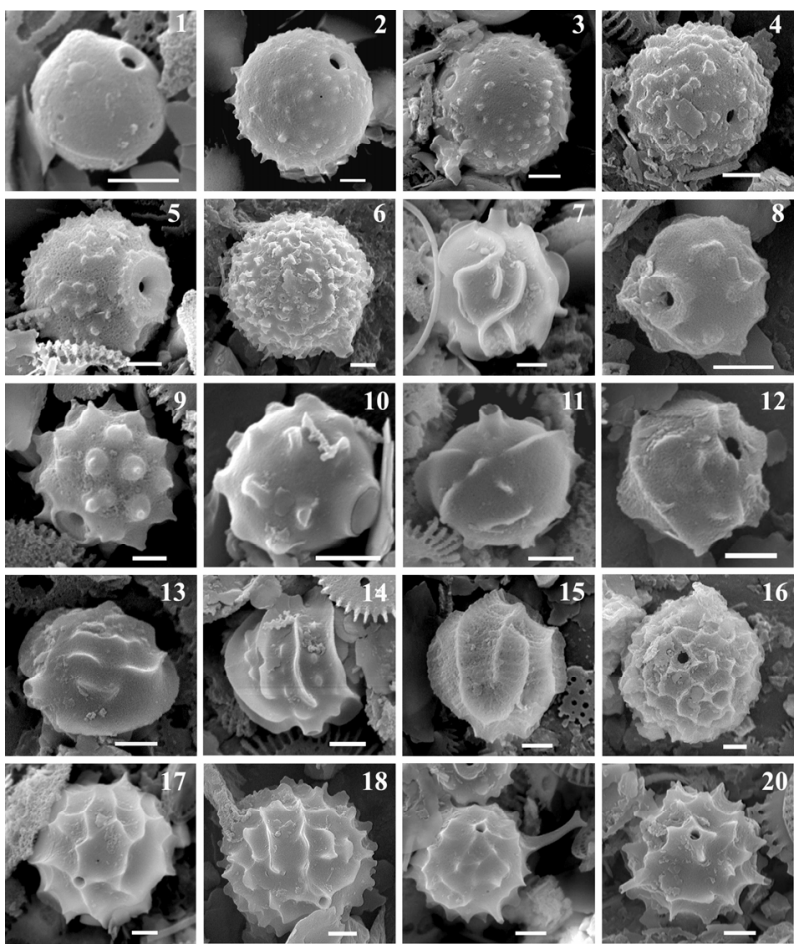

Figure 3. Novel morphotypes of chrysophycean stomatocysts found in the Upper Pleistocene to Holocene sediments from Lake Hovsgol (SEM images): (1) Stomatocyst $\mathrm{H8}$ Firsova; (2) Stomatocyst H9 Firsova; (3) Stomatocyst H10 Firsova; (4) Stomatocyst H12 Firsova; (5) Stomatocyst H13 Firsova; (6) Stomatocyst H14 Firsova; (7) Stomatocyst H19 Firsova; (8) Stomatocyst H20 Firsova; (9) Stomatocyst H22 Firsova; (10) Stomatocyst H25 Firsova; (11) Stomatocyst H26 Firsova; (12) Stomatocyst H27 Firsova; (13) Stomatocyst H28 Firsova; (14) Stomatocyst H29 Firsova; (15) Stomatocyst H32 Firsova; (16) Stomatocyst H34 Firsova; (17) Stomatocyst H36 Firsova; (18) Stomatocyst H38 Firsova; (19) Stomatocyst H39 Firsova; (20) Stomatocyst H40 Firsova. Scale bar: $2 \mu \mathrm{m}$.

$1 \mu \mathrm{m}$ long; a total of about 40) are arranged in four to six rows. The pore is cone-shaped, $1.5 \mu \mathrm{m}$ in diameter, without the annulus.

Stomatocyst H12 Firsova (Figure 3(4))

Taxonomic position: Unknown.

Image no.: 8101-3.

Location: The Upper Pleistocene and Holocene, Lake Hovsgol.

SEM description: The stomatocyst is spherical, 7.8 $8.2 \mu \mathrm{m}$ in diameter. The collar is absent. The whole surface is ornamented with complex verrucous processes up to $0.6 \mu \mathrm{m}$ long, which are often fused with each other (their total number exceeds 50). Part of the processes are swollen at the base. The pore is cylindrical, $0.8-1 \mu \mathrm{m}$ in diameter, without the annulus.

Stomatocyst H13 Firsova (Figure 3(5))

Taxonomic position: Unknown.

Image no.: 8138-2. 
Location: The Holocene, Lake Hovsgol.

SEM description: The stomatocyst is spherical, 8.9 $\mu \mathrm{m}$ in diameter. The cylindrical collar (diameter $3.8 \mu \mathrm{m}$, height $0.8 \mu \mathrm{m})$ has a wide $(1 \mu \mathrm{m})$ planar apex; the lateral surface of the collar is ornamented with small verrucae. The ornamentation of the cyst surface consists of irregularly spaced verrucous and spinelike processes (the former 0.2 - $0.4 \mu \mathrm{m}$ in diameter, the latter 0.2 - $0.5 \mu \mathrm{m}$ long; a total of over 50); come of them are fused into small crests. The bases of crests and spines are swollen or flattened. The pore is cone-shaped, $0.6 \mu \mathrm{m}$ in diameter, without the annulus.

\section{Stomatocyst H14 Firsova (Figure 3(6))}

Taxonomic position: Unknown.

Image no.: 8106-21.

Location: The Holocene, Lake Hovsgol.

SEM description: The stomatocyst is spherical, 13 $\mu \mathrm{m}$ in diameter, with a cylindrical collar (diameter 1.5 $\mu \mathrm{m}$, height $1.5 \mu \mathrm{m})$. The whole stomatocyst surface is densely covered with small $(0.5-0.7 \mu \mathrm{m}$ long $)$ tubular processes or complex processes with shapeless swellings at the apex (a total of over 100). The bases of the processes are swollen or flattened. The pore is cylindrical, 0.7 $\mu \mathrm{m}$ in diameter.

Stomatocyst H19 Firsova (Figure 3(7))

Taxonomic position: Unknown.

Image no.: 8136-2.

Location: The Upper Pleistocene and Holocene, Lake Hovsgol.

SEM description: The stomatocyst is spherical, 8.9 $\mu \mathrm{m}$ in diameter, with a cone-shaped collar (diameter 1.4 $\mu \mathrm{m}$, height $1.1 \mu \mathrm{m}$ ). The whole stomatocyst surface is ornamented with curved crests up to $0.6 \mu \mathrm{m}$ high, differing in length (a total of about 20), some of them swollen at the base. The pore is cylindrical, $1 \mu \mathrm{m}$ in diameter, without the annulus.

Stomatocyst H20 Firsova (Figure 3(8))

Taxonomic position: Unknown.

Image no.: 8101-65.

Location: The Holocene, Lake Hovsgol.

SEM description: The stomatocyst is spherical, 4.6 $\mu \mathrm{m}$ in diameter. The cylindrical collar (diameter $2.4 \mu \mathrm{m}$, height $0.4 \mu \mathrm{m})$ has a wide $(0.6 \mu \mathrm{m})$ planar apex. The surface ornamentation consists of approximately $20 \mathrm{ir}-$ regularly spaced, complex verrucous processes (diameter $0.8-1.2 \mu \mathrm{m}$, length $0.2-0.4 \mu \mathrm{m}$ ) and four to five small, curved crests (length $0.8-2 \mu \mathrm{m}$, height $0.2 \mu \mathrm{m}$ ). The pore is cylindrical, $0.6 \mu \mathrm{m}$ in diameter, without the annulus.

Stomatocyst H22 Firsova (Figure 3(9))

Taxonomic position: Unknown.

Image no.: 8137-11.

Location: The Upper Pleistocene and Holocene, Lake Hovsgol.
SEM description: The stomatocyst is spherical, 8.4 $\mu \mathrm{m}$ in diameter. The collar is slightly conical (diameter $2.8 \mu \mathrm{m}$, height $0.5 \mu \mathrm{m}$ ), with a rounded apex and five to six lateral buttresses. The surface ornamentation consists of about 40 dome-shaped processes (base diameter 1.5 $\mu \mathrm{m}$, height $0.5 \mu \mathrm{m}$ ) with pointed apexes (height $0.2-0.6$ $\mu \mathrm{m})$, elongated or bent into a hook. The pore is cylindri$\mathrm{cal}, 1 \mu \mathrm{m}$ in diameter, surrounded by a depressed annulus $0.6 \mu \mathrm{m}$ wide.

\section{Stomatocyst H25 Firsova (Figure 3(10))}

Taxonomic position: Unknown.

Image no.: 8149-11.

Location: The Holocene, Lake Hovsgol.

SEM description: The stomatocyst is slightly oblate, $5.6 \mu \mathrm{m}$ in diameter and $5 \mu \mathrm{m}$ in height. The collar is cone-shaped (diameter $2 \mu \mathrm{m}$, increasing to $2.5 \mu \mathrm{m}$ at the base), with a rounded apex. The stomatocyst surface is ornamented with short, relatively thick crests $0.6-1.2$ $\mu \mathrm{m}$ long and $0.3-0.5 \mu \mathrm{m}$ high (a total of about 25 ). The bases of the crests are sometimes widened. The pore is closed with a plug.

\section{Stomatocyst H26 Firsova (Figure 3(11))}

Taxonomic position: Unknown.

Image no.: 8132-10.

Location: The Holocene, Lake Hovsgol.

SEM description: The stomatocyst is spherical, 6.2 $\mu \mathrm{m}$ in diameter. The collar is cylindrical (diameter 0.9 $\mu \mathrm{m}$, height $0.8 \mu \mathrm{m}$ ), with a pointed apex and two to three small buttresses at the base. The stomatocyst surface is irregularly ornamented with crests of different lengths $(0.7-3.5 \mu \mathrm{m})$, their height varying from 0.3 to $0.8 \mu \mathrm{m}$ (a total of about 20). The bases of the crests are plain. The pore is cylindrical, $0.7 \mu \mathrm{m}$ in diameter, without the annulus.

Stomatocyst H27 Firsova (Figure 3(12))

Taxonomic position: Unknown.

Image no.: 8146-29.

Location: The Holocene, Lake Hovsgol.

SEM description: The stomatocyst is spherical, 5.7 $\mu \mathrm{m}$ in diameter, without the collar. Its whole surface is irregularly ornamented with crests of different lengths $(0.6-2 \mu \mathrm{m}$ ), their height varying from 0.3 to $0.7 \mu \mathrm{m}$ (a total of about 20); one continuous crest, $0.5-0.8 \mu \mathrm{m}$ high, girdles the stomatocyst along the equator. The pore is cylindrical, $1 \mu \mathrm{m}$ in diameter, without the annulus.

Stomatocyst H28 Firsova (Figure 3(13))

Taxonomic position: Unknown.

Image no.: 8101-51.

Location: The Upper Pleistocene and Holocene, Lake Hovsgol.

SEM description: The stomatocyst is spherical, 6.4 $\mu \mathrm{m}$ in diameter. The collar is cone-shaped (diameter 0.8 $\mu \mathrm{m}$, increasing to $1.3 \mu \mathrm{m}$ at the base; height $0.7 \mu \mathrm{m}$ ), with a rounded apex. The surface is irregularly orna- 
mented with curved crests $0.2-0.5 \mu \mathrm{m}$ high and $1.5-3.2$ $\mu \mathrm{m}$ long (a total of about 15$)$; one high $(0.4-0.7 \mu \mathrm{m})$ continuous crest girdles the stomatocyst along the equator. The bases of the crests are widened. The pore is cylindrical, $0.5 \mu \mathrm{m}$ in diameter, without the annulus.

Stomatocyst H29 Firsova (Figure 3(14))

Taxonomic position: Unknown.

Image no.: 8134-10.

Location: The Upper Pleistocene and Holocene, Lake Hovsgol.

SEM description: The stomatocyst is spherical, 7.2 $\mu \mathrm{m}$ in diameter. The collar is cone-shaped (diameter 1 $\mu \mathrm{m}$, increasing to $1.5 \mu \mathrm{m}$ at the base; height $0.8 \mu \mathrm{m}$ ), with a rounded apex. The surface ornamentation consists of approximately ten high $(0.5-1.0 \mu \mathrm{m})$, continuous longitudinal crests interspaced with small longitudinal crests, $0.2-0.5 \mu \mathrm{m}$ high and $0.5-1 \mu \mathrm{m}$ long (a total of about 30 ). The bases of the crests are plain or widened. The pore is cylindrical, without the annulus.

Stomatocyst H32 Firsova (Figure 3(15))

Taxonomic position: Unknown.

Image no.: 8137-2.

Location: The Holocene, Lake Hovsgol.

SEM description: The stomatocyst is spherical, 8.8 $\mu \mathrm{m}$ in diameter. The collar is cone-shaped (diameter 1.2 $\mu \mathrm{m}$, increasing to $2.2 \mu \mathrm{m}$ at the base; height $0.7 \mu \mathrm{m}$ ), with a pointed apex. The stomatocyst surface is ornamented with six to seven continuous longitudinal or coiled crests (height $0.2-0.9 \mu \mathrm{m}$ ). The lateral surfaces of the ridges, throughout their height, are covered with transverse grooves. The data on pore structure are absent.

Stomatocyst H34 Firsova (Figure 3(16))

Taxonomic position: Unknown.

Image no.: 8105-46.

Location: The Upper Pleistocene and Holocene, Lake Hovsgol.

SEM description: The stomatocyst is spherical, 15.5 $15.8 \mu \mathrm{m}$ in diameter, without the collar. Its surface has an irregular reticulate ornamentation consisting of more than 50 compartments with a diameter ranging from 1.5 to $3.6 \mu \mathrm{m}$. The pore is cylindrical, $1.5 \mu \mathrm{m}$ in diameter, without the annulus.

Stomatocyst H36 Firsova (Figure 3(17))

Taxonomic position: Unknown.

Image no.: 8140-9.

Location: The Upper Pleistocene and Holocene, Lake Hovsgol.

SEM description: The stomatocyst is spherical, 12 $\mu \mathrm{m}$ in diameter. The collar is cone-shaped (diameter 1 $\mu \mathrm{m}$, height $0.8 \mu \mathrm{m}$ ), with a pointed apex. The whole stomatocyst surface is irregularly ornamented with interconnected crests differing in length $(1-5 \mu \mathrm{m})$ and height $(0.5-1.2 \mu \mathrm{m})$, which form a reticulate pattern. Some crests are fused with the collar. The pore is cylin- drical, $0.8 \mu \mathrm{m}$ in diameter, without the annulus.

Stomatocyst H38 Firsova (Figure 3(18))

Taxonomic position: Unknown.

Image no.: 8101-58.

Location: The Holocene, Lake Hovsgol.

SEM description: The stomatocyst is spherical, 11.3 $\mu \mathrm{m}$ in diameter. The collar is cone-shaped (diameter 1.2 $\mu \mathrm{m}$, increasing to $1.8 \mu \mathrm{m}$ at the base; height $1 \mu \mathrm{m})$, with a rounded apex. The surface ornamentation consists of small crests, 5.5 - $1 \mu \mathrm{m}$ long and $0.6-1 \mu \mathrm{m}$ high (a total of about 30), with jagged edges sometimes extending into spines. Three to four crests on the anterior surface are fused with the collar. The pore is funnel-shaped, 0.7 $\mu \mathrm{m}$ in diameter, without the annulus.

Reference: This morphotype is similar to the stomatocyst 247 Firsova \& Likhoshway from Lake Baikal sediments, but its size is larger and the collar is higher.

Stomatocyst H39 Firsova (Figure 3(19))

Taxonomic position: Unknown.

Image no.: 8136-15.

Location: The Holocene, Lake Hovsgol.

SEM description: The stomatocyst is spherical, 8.4 $\mu \mathrm{m}$ in diameter. The collar is cone-shaped (diameter 0.8 $\mu \mathrm{m}$, height $0.6 \mu \mathrm{m}$ ), with a pointed apex and five lateral buttresses (ridges). The surface ornamentation consists of scattered or interconnected ridges, $1.5-2.7 \mu \mathrm{m}$ long and $0.5-0.8 \mu \mathrm{m}$ high (a total of about 40), passing into small spines $(0.5-0.8 \mu \mathrm{m}$; two to four long spines $(4.5-6 \mu \mathrm{m})$ bifurcated at the tips; and two to four tubular processes (1.4 - $1.7 \mu \mathrm{m}$ long). The bases of the processes are widened. The pore is cylindrical, $0.6 \mu \mathrm{m}$ in diameter, without the annulus.

Stomatocyst H40 Firsova (Figure 3(20))

Taxonomic position: Unknown.

Image no.: 8141-11.

Location: The Upper Pleistocene and Holocene, Lake Hovsgol.

SEM description: The stomatocyst is spherical, 8.5 $\mu \mathrm{m}$ in diameter. The collar is cone-shaped (diameter 0.8 $\mu \mathrm{m}$, increasing to $1.3 \mu \mathrm{m}$ at the base; height $0.5 \mu \mathrm{m}$ ), with a pointed apex. The stomatocyst surface is irregularly ornamented with short, pointed crests $1-3 \mu \mathrm{m}$ long and $0.9-1.3 \mu \mathrm{m}$ high, which sometimes fuse with each other (a total of about 20); spinelike processes $0.9-2.5$ $\mu \mathrm{m}$ long (about 15); and tubular processes $0.6-2.3 \mu \mathrm{m}$ long (about 6). The processes are widened at the base. The pore is cylindrical, $0.5 \mu \mathrm{m}$ in diameter, without the annulus.

Other morphotypes of chrysophycean stomatocysts found in bottom sediments from Lake Hovsgol have been described previously.

Smooth, unornamented stomatocysts $4-15 \mu \mathrm{m}$ in diameter, having 0.8 - to $1.2-\mu \mathrm{m}$ pores with or without the annulus (Figures 4(1) and (2)), are frequent in sediments of 


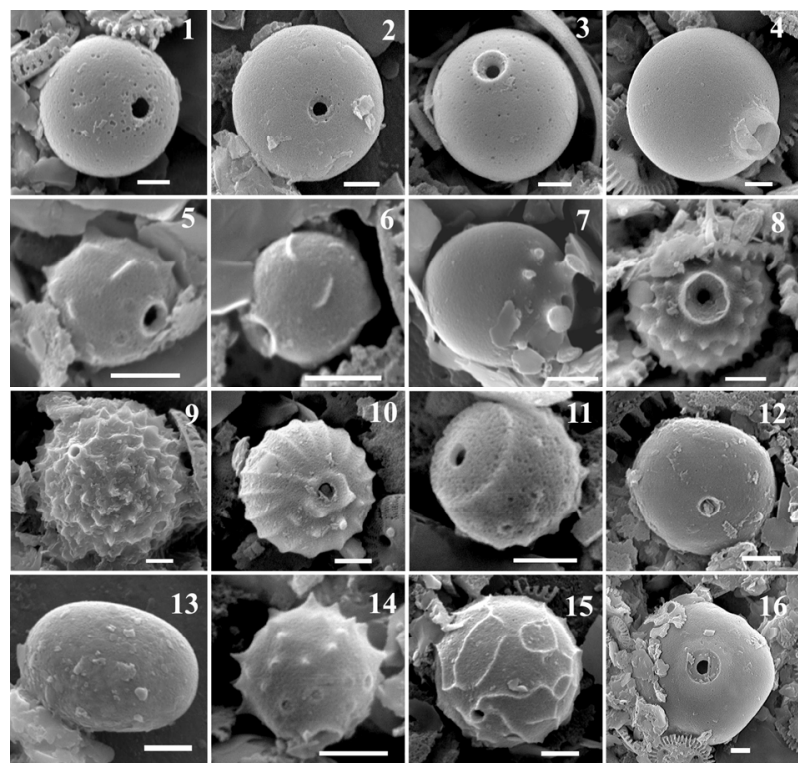

Figure 4. Previously known morphotypes of chrysophycean stomatocysts found in the Upper Pleistocene to Holocene sediments from Lake Hovsgol (SEM images): (1), (2) GH1; (3), (4) GH2; (5) Stomatocyst 5 Duff \& Smol forma A Duff \& Smol; (6) Stomatocyst 33 Zeeb \& Smol; (7) Stomatocyst 136 Duff \& Smol; (8) Stomatocyst 157 Zeeb \& Smol; (9) Stomatocyst 212 Firsova \& Likhoshway; (10) Stomatocyst 228 Duff \& Smol; (11) Stomatocyst 331 Firsova; (12) Stomatocyst 132 Firsova \& Likhoshway; (13) Stomatocyst 118 Cronberg; (14) Stomatocyst S005C Pla; (15) Stomatocyst 179 forma B, Zeeb \& Smol; (16) Stomatocyst 156 Zeeb \& Smol. Scale bar: $2 \mu \mathrm{m}$.

different ages, up to $3 \mathrm{Ma}$ [13], and have been described from Lake Baikal [15] as well as from other water bodies [13]. Such morphotypes are similar to stomatocysts 1, 9, 15, 29, and 42 Duff \& Smol, 1988 [13] and to stomatocysts $101,103,104,130,118$, and 127 Firsova \& Likhoshway from Lake Baikal sediments [15]. According to Duff et al. (1995), smooth stomatocysts without the collar may be produced by several species such as Paraphysomonas vestita (Stokes) De Saedeler, Chrysosphaerella longispina Lauterborn, Chrysphaerella brevispina Korshikov emend. Harris et Bradley, Mallomonas striata Asmund, Chrysolepidomonas dendrolepidota Peter \& Andersen, and Synura petersenii Korshikov. The majority of species producing such stomatocyst morphotypes live in fresh waters and are tolerant to a wide range of environmental conditions (including $\mathrm{pH}$ and salinity), but prefer relatively low temperatures. Some of them are responsible for algal bloom [17].

Smooth collared stomatocysts $4-12 \mu \mathrm{m}$ in diameter (Figures 4(3) and (4)) have been found in the bottom sediments and plankton of several water bodies. They show similarity to stomatocysts $50,51,52,110,123,126$, 127, 197, and 234 Duff \& Smol found in sediment and plankton samples from the United States, Canada, Poland, and Greenland [13] and also to stomatocysts 119, 131, 134 Firsova \& Likhoshway from Lake Baikal sediments and plankton [15]. Such cysts are produced by widespread species of the genus Synura, e.g., S. curtispina (Petersen \& Hansen) Asmund, and also by Dinobryon cylindricum, Paraphysomonas antarctica Takahashi, $P$. vestita (Stokes) De Saedeler, and P. corynephora Preisig \& Hibberd [13]. These species have a broad spectrum of ecological tolerance and sometimes cause algal bloom [13].

Since unornamented stomatocysts could be produced by several species each, morphotypes without the collar and with the collar were pooled into individual groups (GH1 and GH2, respectively; see Figure 4) when their distribution in bottom sediments was analyzed.

Stomatocyst 5 Duff \& Smol form A Duff \& Smol (Figure 4(5)) has been found in the waters of Canada (Northeast Territories, British Columbia) and the United States (New York, Minnesota, California, Washington). This morphotype is produced by species characteristic of deep and cold oligotrophic lakes and tolerant of a wide $\mathrm{pH}$ range [13].

Stomatocyst 33 Zeeb \& Smol 1994 (Figure 4(6)) has been found in Canada (Northwestern Territories, Ontario: cyst 17, Rybak et al., 1987), the United States (Minnesota), Denmark (cysta stellata Nygaard, 1956), and Poland. This morphotype is produced by cold-water taxa tolerant of a wide $\mathrm{pH}$ range and is characteristic of deep lakes [13].

Stomatocyst 136 Duff \& Smol [13] (Figure 4(7)). This is a widespread morphotype found in the United States (California, Connecticut), Canada (Northeast Territories, Yukon, British Columbia: Carnegia arvernensis Andrieu 1977), Spain (formae 36 and 37; Rull 1986, 1991), Italy (Cleicia sp. A), the Kerguelen Islands in the Indian Ocean (Carnegia deflandrei Andrieu), and Argentina [13]. It occurs in shallow waters and is probably produced by littoral (periphyton) species [13].

Stomatocyst 157 Zeeb \& Smol 1993 (Figure 4(8)) has been found in the United States (Minnesota, New York) in sediments dated 1851 AD. This morphotype is attributed to cold water-tolerant species with a broad trophic status [13].

Stomatocyst 212 Firsova \& Likhoshway (Figure 4(9)) is characteristic of Lake Baikal Holocene sediments.

Stomatocyst 228 Duff \& Smol (Figure 4(10)) has been found in the United States (Minnesota) and Canada (British Columbia) [13]. It occurs in lakes with a low water $\mathrm{pH}(6.8)$, alkalinity of $6.3 \mathrm{mg} / \mathrm{l}$, and total dissolved phosphorus of $5.4 \mu \mathrm{g} / \mathrm{l}$ (Rybak et al., 1987); cited from (Duff et al., 1995).

Stomatocyst 331 Firsova (Figure 4(11)) has been found in the recent Lake Baikal plankton [15].

Morphotypes represented in Lake Hovsgol sediments 
by single specimens were as follows: stomatocyst 132 Firsova \& Likhoshway previously described from Lake Baikal sediments; stomatocyst 118 [18] attributed to the species Mallomonas akrokomos; the widespread stomatocyst 179 forma B, Zeeb \& Smol, 1993 (Duff et al., 1995); stomatocyst S005C (Pla, 1999) found in the surface layer of bottom sediments from Lake Redó (Spain); and stomatocyst 156 Zeeb \& Smol from bottom sediments of Lake Elk, Minnesota (the United States), which is morphologically similar to stomatocyst 121 Firsova \& Likhoshway from Lake Baikal [15] but has a larger size.

\section{Discussion}

\subsection{Distribution of Stomatocyst Morphotypes over the Core Depth}

Stomatocyst morphotypes differed in their distribution pattern in the HUB 01-01 sediment core (Figure 2). Some morphotypes, varying in numbers, occurred almost at all depths where diatoms were found. In particular, these were stomatocysts of the GH1 group, stomatocyst 157 Zeeb \& Smol, and stomatocysts H12, H22, H29, H34, and H36. This could be expected for the GH1 group, since it comprised representatives of different taxa. In the case of stomatocyst 157 , such a distribution could be due to a broad trophic status of the corresponding species [13]. It is noteworthy that stomatocysts 5, 33, 157, 212 and H12, H22, H29, H36 were recorded in the interval (2) together with the diatom $C$. ocellata, which appeared in the Late Pleistocene ecosystem of the lake, and then accompanied this species up to the recent sediment layer. Since stomatocysts 5, 33, 157, and 212 have previously been found mainly in cold water bodies [13], it appears that novel morphotypes (stomatocysts H12, H22, H29, and H36) also belong to cold-loving species.

Four morphotypes proved to occur only at certain nonoverlapping depths of Holocene sediments, forming narrow abundance peaks: stomatocyst 136 , at a depth of $20 \mathrm{~cm} ; \mathrm{H} 9$, at 40, 44, and $46 \mathrm{~cm} ; \mathrm{H} 13$, at 43, 49, and 56 $\mathrm{cm}$; and $\mathrm{H} 39$, at 46,47 , and $51 \mathrm{~cm}$. Stomatocyst 136 was found at the local minimum of the total diatom concentration in bottom sediments, which could be explained by preferential association of this morphotype with shallow waters [13]. A feasible explanation to specific distribution patterns of the other three morphotypes has not yet been found

The morphotypes previously described from the plankton (stomatocyst 331) and Holocene sediments of Lake Baikal (stomatocyst 212) [15] occurred almost throughout the sediment core, from the Upper Pleistocene to recent layers.

\subsection{Diversity of Stomatocyst Morphotypes}

The highest diversity of morphotypes (without groups
GH1 и GH2), including those not presented in the diagram (Figure 2), was revealed at the following depths of the sediment core: $10 \mathrm{~cm}$ (13 morphotypes); 1, 2, 24, 40 cm (12 morphotypes); 46, 49, $76 \mathrm{~cm}$ (11 morphotypes); 8 , 21, 26, $56 \mathrm{~cm}$ (10 morphotypes); and 20, $47 \mathrm{~cm}$ (9 morphotypes each). Four to six dominant morphotypes (in the absence of any other morphotypes) were recorded at depths of $36,38,53,77$, and $78 \mathrm{~cm}$.

Thus, it is apparent that layers with high and low diversity of stomatocysts alternate with each other in the sediment core, which is evidence for a series of changes in environmental conditions in the paleo-Lake Hovsgol. In general, a higher diversity is characteristic of sediments formed in the first half of the Holocene (56 - 36 $\mathrm{cm}$ ), when the cold-loving diatom $C$. bodanica actively developed in the lake: these sediments contain 19 morphotypes of chrysophycean stomatocysts, compared to 14 morphotypes in sediments formed in the second half of the Holocene (in addition, both sediment layers contain stomatocysts of the GH1 и GH2 groups).

\subsection{Composition of Dominant Stomatocyst Assemblages}

The dominant assemblages of stomatocysts were identified by the contributions of individual morphotypes to their total contents in each layer of the sediment core (Figure 2). It can be seen that the composition of dominant morphotypes and their groups changed with the core depth.

- Stomatocyst H22 was dominant throughout the core depth except for the uppermost layer $(0-1 \mathrm{~cm})$, where its proportion among all morphotypes decreased to $3 \%$, compared to $13 \%$ in the underlying layer (1 - 2 $\mathrm{cm})$.

- The proportion of novel morphotypes reached $40 \%$ at the depth of $53 \mathrm{~cm}$. As indicated by the distribution of diatoms and biogenic silica, the corresponding period was characterized by climate warming and humidification [19]. It is also noteworthy that the endemic diatom Stephanodiscus mongolicus appeared in this period.

- A decrease in the diversity of the dominant stomatocyst assemblage was observed at the depth of $7-8 \mathrm{~cm}$ (the Holocene). This assemblage at $7 \mathrm{~cm}$ consisted of eight morphotypes with the prevalence of stomatocyst 212 Firsova \& Likhoshway (24\%) and stomatocyst 157 Zeeb \& Smol (21\%), compared to 11 morphotypes with the prevalence of stomatocyst H22 (22\%) at $8 \mathrm{~cm}$.

- At the depth of $53 \mathrm{~cm}$, where the D/S index was high (19.5), the most prevalent morphotypes were stomatocyst 223 Duff \& Smol (20\%) and stomatocyst H22 (20\%). 
- At the depth of $76 \mathrm{~cm}$, where the $\mathrm{D} / \mathrm{S}$ index was low (2.8), the assemblage was dominated by different morphotypes, namely, by stomatocysts $\mathrm{H} 19$ and $\mathrm{H} 12$.

- The assemblages observed at depths of 1 and $21 \mathrm{~cm}$ had a similar composition, both being dominated by stomatocyst $\mathrm{H} 12$ (29\% and 32\%, respectively).

The highest diversity of stomatocyst morphotypes was observed in the core segment between 56 and $36 \mathrm{~cm}$, where we distinguished three intervals characterized by obvious dominance of certain morphotypes. Their assemblages at depths of 38 and $43 \mathrm{~cm}$ were dominated by stomatocyst 5 Duff \& Smol (17\% and 20\%) and stomatocyst $\mathrm{H} 22$ (23\% and 20\%, respectively) (Figure 2), against the background of slight decrease in the total numbers of both diatoms and stomatocysts (note that stomatocyst H22 is a novel morphotype described here for the first time). The assemblage at the depth of $53 \mathrm{~cm}$, where the diversity of morphotypes was lower than in the previous two layers, was dominated by stomatocyst H19, which accounted for $27 \%$ of the total number of stomatocysts. This layer was also characterized by the appearance of the diatom Stephanodiscus mongolicus.

\subsection{Significance of the $D / C$ Index}

The ratio of diatom frustules to chrysophycean stomatocysts $(\mathrm{D} / \mathrm{C})$ is indicative of a certain structural state of the microalgal community, either at present [20] or in the past $[16,21,22]$.

The highest $\mathrm{D} / \mathrm{C}$ value (35.1) was recorded in the interval (2) at a core depth of $78 \mathrm{~cm}$. An important fact is that this layer was also characterized by the maximum development of benthic diatoms and the appearance of planktonic diatoms (Figure 2), with the contents of organic carbon and nitrogen in it being indicative of increasing biological production in the Lake Hovsgol catchment area [19]. These data indicate that this sediment layer was formed when the water level in the lake was medium and the trophic level was the highest over the whole time period represented in the core.

In close vicinity to this layer, at a depth of $76 \mathrm{~cm}$, the $\mathrm{D} / \mathrm{C}$ index dropped to 2.8. Conditions in the corresponding period were unfavorable for the development of planktonic species (including chrysophyte algae) because of a low water level in the lake, and benthic diatoms dominated in bottom sediments.

Between 76 and $63 \mathrm{~cm}$ (interval 3), the $\mathrm{D} / \mathrm{C}$ values were generally low, varying from 1.5 to 7.4 ; i.e., contemporary conditions could be considered more favorable for the development of chrysophyte algae than of planktonic diatoms. However, the total numbers of stomatocysts in sediments were small, while benthic diatoms occurred in relatively high concentrations. Nevertheless, the $\mathrm{D} / \mathrm{C}$ values indicate that the beginning of the above interval can be regarded as the most oligotrophic period in the paleorecords studied, since its distinctive feature is a considerable diversity of stomatocyst morphotypes.

The next interval (4) was characterized by active colonization of the Holocene lake by both diatoms and chrysophyte algae simultaneously. The $\mathrm{D} / \mathrm{C}$ index sharply increased at $62 \mathrm{~cm}$ and remained high (15.3 - 30.8) up to $54 \mathrm{~cm}$, which may be evidence that the rise of water level in the lake was accompanied by an increase in its trophicity.

The highest concentrations of stomatocysts were found in the interval (5) characterized by active development of diatoms C. ocellata, S. mongolicu, and C. bodanica. Therefore, the corresponding period was most favorable for both diatoms and chrysophyte algae, with the average $\mathrm{D} / \mathrm{C}$ value varying from 8.0 to 20.8 (in the time before present) and stabilizing at $\mathrm{D} / \mathrm{C}=17.7$ in the upper (recent) layer of bottom sediments.

\section{Conclusions}

Bottom sediments from Lake Hovsgol contain a wide diversity of stomatocyst morphotypes, which exceeds that of recent species of chrysophyte algae recorded in the lake. The same is true, e.g., of Lake Baikal sediments [15]. Moreover, chrysophycean stomatocysts from Lake Hovsgol are no less diverse than planktonic diatom species: they are represented by at least 36 morphotypes, including 20 unique morphotypes described for the first time. Not only the concentration of stomatocysts but also the composition of their dominant assemblages changes with depth down the sediment profile. The highest diversity of morphotypes is observed in layers corresponding to the periods of development of the cold-water diatom Cyclotella bodanica. The most abundant in sediments are smooth (unornamented) morphotypes; typical of Lake Hovsgol are morphotypes H12, H19, and H22 (Figures 3(4), (7) and (9)), which occur throughout the core depth and, in certain intervals, account for up to $40 \%$ of the total stomatocyst abundance. Intervals (2) and (4) correspond to periods when the dried-up southern lake area was again filled with water and the trophic level of the lake increased temporarily. They are characterized by the highest $\mathrm{D} / \mathrm{C}$ values.

Thus, the diversity of microalgal paleocommunity in Lake Hovsgol is accounted for by chrysophycean stomatocysts as well as by diatoms. Data on changes in the total abundance ratio of diatom frustules to stomatocysts, the diversity of stomatocyst morphotypes, and specific features of their distribution in bottom sediments are of high information value for analyzing the paleorecords of the lake and, hence, deserve special attention.

\section{Acknowledgements}

We are grateful to M. M. Maslennikova for making SEM 
images, to A. P. Fedotov for providing the HUB 01-01 sediment core for analysis, and for his valuable comments on the manuscript. This work was supported by the Biological Diversity Program of the Presidium of the Russian Academy of Sciences, project no. 26.12.

\section{REFERENCES}

[1] A. P. Fedotov, E. V. Bezrukova, S. S. Vorobyova, O. M. Khlystov, O. V. Levina, I. B. Mizandrontsev, G. F. Mazepova, A. R. Semenov, T. O. Zheleznyakova, S. M. Krapivina, E. P. Chebykin and M. A. Grachev, "Bottom Sediments of Lake Hovsgol as Annals of Holocene and Late Pleistocene Paleoclimates," Geologia i Geofizika, Vol. 42, No. 1-2, 2001, pp. 384-390.

[2] A. P. Fedotov, E. P. Chebykin, M. Yu. Semenov, S. S. Vorobyova, E. Yu. Osipov, L. P. Golobokova, T. V. Pogodaeva, T. O. Zheleznyakova, M. A. Grachev, D. Tomurhuu, Ts. Oyunchimeg, Ts. Narantsetseg, O. Tomurtogoo, P. T. Dolgikh, M. I. Arsenyuk and M. De Batist "Changes in the Volume and Salinity of Lake Khubsugul (Mongolia) in Response to Global Climate Changes in the Upper Pleistocene and the Holocene," Palaeogeography, Palaeoclimatology, Palaeoecology, Vol. 209, No. 1-4, 2004, pp. 245-257. doi:10.1016/j.palaeo.2003.12.022

[3] A. Yu. Kazansky, A. P. Fedotov, G. G. Matasova, A. A. Yuldashev, G. A. Ziborova, T. O. Zheleznyakova, E. G. Vologina, T. S. Oyuunchimeg, Ts. Narantsetseg and D. Tomurkhu, "Initial Results of Paleomagnetic Studies on Bottom Sediments of Lake Hovsgol: Drilling Data," Geologia i Geofizika, Vol. 46, No. 4, 2005, pp. 448-451

[4] A. A. Prokopenko, G. K. Khursevich, E. V. Bezrukova, M. I. Kuzmin, X. Boes, D. F. Williams, S. V. Fedenya, N. V. Kulagina, P. P. Letunova and A. A. Abzaeva, "Paleoenvironmental Proxy Records from Lake Hovsgol, Mongolia, and a Synthesis of Holocene Climate Change in the Lake Baikal Watershed," Quaternary Research, Vol. 68, No. 1, 2007, pp. 2-17. doi:10.1016/i.yqres.2007.03.008

[5] A. A. Abzaeva, E. V. Bezrukova, V. A. Bychinskii, V. F. Geletii, A. V. Goreglyad, E. V. Ivanov, G. V. Kalmychkov, E. V. Kerber, M. A. Krainov, M. I. Kuzmin, N. V. Kulagina, P. P. Letunova, Yu. V. Osukhovskaya, E. P. Solotchina, L. L. Tkachenko, M. Y. U. Khomutova, G. Inouie, T. Kavai, K. Kashivaiya, K. Minoura, K. H. Sakai, T. S. Narantsetseg, T. S. Oyunchimeg, D. Tomurkhuu, D. I. Kim, A. A. Prokopenko, S. A. Fedenya and G. K. Khursevich, "Structure of Lake Hovsgol Bottom Sediments: Relationships with Geological and Climatic Factors," Geologia i Geofizika, Vol. 48, No. 11, 2007, pp. 1117-1143.

[6] A. A. Prokopenko, G. K. Khursevich, M. I. Kuzmin and T. Kawai, "Productivity Cycles in Lake Hovsgol, NW Mongolia, during the Last $1 \mathrm{Ma}$ and the Age Model of the HDP-04 Drill Core Record," Quaternary International, Vol. 205, 2009, pp. 111-125. doi:10.1016/j.quaint.2009.02.030

[7] G. K. Khursevich and A. A. Prokopenko, "Diatom Record from Lake Hovsgol, Mongolia, during the Last $1 \mathrm{Ma}$
The Results from the HDP-04 Drill Core," Quaternary International, Vol. 205, 2009, pp. 84-97. doi:10.1016/j.quaint.2009.02.003

[8] N. I. Dorofeyuk and P. E. Tarasov, "Vegetation and Water Levels in Lakes of Northern Mongolia over the Past 12,500 Years According to Data of Palynological and Diatom Analyses," Stratigraphy and Geological Correlation, Vol. 6, No. 1, 1998, pp. 73-87.

[9] S. S. Vorobyova, "Diatom Complexes of Lake Hovsgol," Abstracts of the International Symposium "The Living Diatom Cell" 100 Years A.P. Skabichevsky Memorial, Irkutsk, 17-22 September 2004, pp. 106-107.

[10] I. V. Makarova, Ed., "Diatomovye Vodorosli SSSR. Iskopaemye i Sovremennye," Nauka, Sankt-Peterburg otdelenie, Sankt-Peterburg, T. 2, No. 2, 1992.

[11] M. A. Grachev, Ye. V. Likhoshway, S. S. Vorobyova, O. M. Khlystov, E. V. Bezrukova, E. V. Veinberg, E. L. Goldberg, L. Z. Granina, E. G. Kornakova, F .Lazo, O. V. Levina, P. P. Letunova, P. V. Otinov, V. V. Pirog, A. P. Fedotov, S. A. Yaskevich, V. A. Bobrov, F. V. Sukhorukov, V. I. Rezchikov, M. A. Fedorin, K. V. Zolotarev and V. A. Kravchinskii, "Signals from the Upper Pleistocene Paleoclimates in Lake Baikal Sediments," Geologia $i$ Geofizika, Vol. 38, No. 5, 1997, pp. 957-980.

[12] G. Cronberg, "Chrysophycean Cysts and Scales in Lake Sediments: A Review," In: J. Kristiansen and R. A. Andersen, Eds., Chrysophytes: Aspects and Problems, Cambridge University Press, Cambridge, 1986, pp. 281-315.

[13] K. E. Duff, B. A. Zeeb and J. P. Smol, "Atlas of Chrysophycean Stomatocysts," Kluwer Academic Publishers, Dordrecht, 1995.

[14] A. N. Wilkinson, B. A. Zeeb and J. P. Smol, "Atlas of Chrysophycean Cysts," Kluwer Academic Publishers, Dordrecht, 2001.

[15] A. D. Firsova and Ye. V. Likhoshway, "Atlas of Chrysophycean Cysts from Lake Baikal," Nauka, Novosibirsk, 2006.

[16] J. P. Smol, "The Ratio of Diatom Frustules to Chrysophycean Statospores: A Useful Paleolimnological Index," Hydrobiologia, Vol. 123, 1985, pp. 199-204. doi:10.1007/BF00034378

[17] R. N. Belyakova, L. N. Voloshko, O. V. Gavrilova, R. M. Gogorev, I. V. Makarova, Yu. B. Okolodkov and L. A. Rundina, "Algae Responsible for Algal Bloom in Water Bodies of Northwestern Russia," KMK Scientific Press, Moscow, 2006.

[18] G. Cronberg, "Cyst Development in Different Species of Mallomonas (Chrysophyseae) Studied by Scanning Electron Microscopy," Archiv für Hydrobiologie, Vol. 56, 1980, pp. 421-434.

[19] T. S. Narantsetseg, "Geochemistry of Lake Hovsgol Bottom Sediments and Paleoclimatic Reconstructions," Extended Abstract of Cand. Sci. (Geol.), Dissertation, Irkutsk, 2007.

[20] A. D. Firsova, A. E. Kuzmina, I. V. Tomberg, T. G. Potemkina and Ye. V. Likhoshway, "Seasonal Dynamics of Chrysophyte Stomatocyst Formation in the Plankton of Southern Baikal," Izvestiya Akademii Nauk SSSR Seriya 
Biologicheskaya, Vol. 5, 2008, pp. 589-596.

[21] H. J. Carney and C. D. Sandgren, "Chrysophycean Cysts: Indicators of Eutrophication in Recent Sediments of Frains Lake, Michigan, USA," Hydrobiologia, Vol. 101, 1983, pp. 195-202. doi:10.1007/BF00009875

[22] E. Magyari, K. Buczko, G. Jakab, M. Braun, Z. Pal, D.
Karatson and I. Pap, "Palaeolimnology of the Last Crater Lake in the Eastern Carpathian Mountains: A Multiproxy Study of Holocene Hydrological Changes," Hydrobiologia, Vol. 631, No. 1, 2009, pp. 29-63. doi:10.1007/s10750-009-9801-1 